\title{
The Effect of Consumer Motivations on Purchase Intention of Online Fashion - Sharing Platform
}

\author{
Jessica WON ${ }^{1}$, Bo-Young KIM ${ }^{2}$
}

Received: March 24, 2020 Revised: April 08, 2020 Accepted: May 05, 2020

\begin{abstract}
This study aims to examine the influence of attitudes on customers' intention to participate in online fashion sharing. A framework was proposed to investigate the relationships between consumer motivation, consumer attitude, and purchase intention in the manner of adopting a fashion-sharing platform. Consumer motivations are divided into three categories: utilitarian, hedonic, and ecological. The moderating effects of product replacement cycle (PRC) on consumer attitude and purchase intention are also investigated. Data collection was developed using a web-based survey where 180 consumer respondents from South Korea participated. The results of our analysis indicate that consumers' hedonic and ecological motivations are positively related to favorable consumer attitudes, even when consumers' utilitarian motivation is denied. Consumer attitude is also positively related to purchase intention in the fashion-sharing platform. A moderating effect of PRC is recorded between consumer attitude and purchase intention based on high and low PRC, as well as the effect of ecological motivation and consumer attitude on high PRC. This study enhances knowledge of consumer motivational factors in a fashion-sharing platform and provides insights for service providers to help them improve their target marketing.
\end{abstract}

Keywords : Online Sharing Platform, Consumer Motivation, Consumer Attitude, Purchase Intention, Fashion Industry

JEL Classification Code : M15, M31, L10, L81

\section{Introduction}

The sharing economy is a fast-growing phenomenon that has significantly disrupted traditional businesses. The sharing economy converges around activities facilitated through digital platforms that enable peer-to-peer access to goods and services (Richardson, 2015). The term "sharing economy" was first coined in 1984 by Martin Weitzman, a professor of economics at Harvard University, and means sharing with others instead of owning real assets (Hamari et al, 2016). In other words, consumers no longer place value on ownership of things, but value their function.

${ }^{1}$ First Author. PhD Candidate, Seoul Business School, aSSIST, South Korea. Email: jmwon@stud.assist.ac.kr.

${ }^{2}$ Corresponding Author. Associate Professor, Seoul Business School, aSSIST, Korea [Postal Address: 46 Ewhayeodae-2-gil, Seodaemun-gu, Seoul, Korea, 03767] Email: bykim2@assist.ac.kr

(c) Copyright: The Author(s)

This is an Open Access article distributed under the terms of the Creative Commons Attribution Non-Commercial License (http://Creativecommons.org/licenses/by-nc/4.0/) which permits unrestricted noncommercial use, distribution, and reproduction in any medium, provided the original work is properly cited.
This new consumer trend is also called "access-based consumption," "collaborative consumption," the "peer economy," or the "collaborative economy" (Lee, 2017). New sharing economy-based business models (SEBMs) using technology have many benefits at the national, organizational, community, and individual levels. Examples of successful sharing economy business models to date are bike sharing (Mobike and OfO), vehicular mobility sharing (Uber and Didi), and accommodation sharing (Airbnb) (Rong et al., 2018). These businesses are based on reliable ICT infrastructure, can manage social inefficiencies, and are a promising way to overcome a recession.

With the rapid progress of science and technology, customer expectations are on the rise, which affects a wide range of industries (Mehrjoo \& Pasek, 2016). Fashion products are among the trendiest items, and consumers share and seek the latest trend in real time. Therefore, the fashion industry today is trapped in a competitive cycle of shorter and faster sales and production periods, requiring continual changing of styles, frequent renewal of products, and rapid availability (Ozdamar-Ertekin, 2016). However, the consumption of fashion products has devastating consequences for the 
environment. This latest trend-oriented consumption has led to a surge in apparel waste, as products used only once or twice are discarded. On average, $50 \%$ of the 64 new pieces of clothing that American women buy per year were only worn once (Nguyen \& Khoa, 2019). In addition, the faster the cycle of clothing replacement, the more vicious the environmental harm in the process of producing more diverse clothes. Individual consumers are also increasingly aware of the environmental impact of clothing. This environmental concern has been shown in several studies as one of the factors of consumers' motivation to consume as a component of the triple bottom line for sustainability (Parguel et al., 2017). Moreover, for access-based consumption, sustainability has been found to be one of the important motivators in previous studies (Hamari et al., 2016). In the Korean fashion industry, access-based and collaborative consumption can come in the form of rental and resale or new business models that can tackle overconsumption. Thus, the role of the sharing platform will be further emphasized for a rational consumption culture to extend the life of products and to prevent overconsumption (Lee, 2017).

The success of sharing platforms is driven by a growing environmental consciousness combined with the ubiquity of the Internet and associated information and communication technologies (ICT) that make sharing possible at scale (Cohen \& Kietzmann, 2014). Fashion rental platforms are also spreading based on ICT, with representative companies including 'Rent the Runway' and 'Bag Borrow' or 'Steal'.

Fashion products are more sensitive to trends than others, but they have a specificity that requires direct contact with the body. Nevertheless, the concept of a sharing platform has been introduced into the fashion industry, and some global companies are growing rapidly both financially and technically. However, research into this new business model in the fashion industry has been limited. In particular, research on the consumption motives of customers who use the system is very limited. Therefore, this study attempted to quantitatively study the consumption motivation of consumers who use fashion sharing platforms.

\section{Literature Review}

\subsection{Fashion Sharing Platform}

The sharing economy has been making headway into the fashion industry. Peer-to-peer collaborative consumption (P2P-CC) is becoming very popular for fashion products in the sharing economy (Choi \& He, 2019). The sharing economy is a way of paying for what you use, and similarly, the subscription economy is a concept in which you pay first and then dictate the goods or services you want, which is well known as the Netflix model (Shin et al., 2019). Fashionsharing services are also called fashion-rental services, fashion-streaming services, etc., and refer to services for sharing clothes. The lifespan of fashion products is becoming more elastic to enable a rental business model for products that were previously the objects of long-term possession. A growing number of customers who have purchased fashion products are now starting to rent them (Yuan \& Shen, 2019). Fashion sharing platforms have been spreading around the world, starting in Europe and the United States in the late 2000s. Rent the Runway, which is a representative commercial business case, is leading the rental market with a subscription service in the United States valued at \$1 billion in 2019. Bag Borrow or Steal in the United States, YCloset in Beijing, GlamCorner in Australia, and Frontrow and Wear the Walk in London are similar examples. The outstanding performance of the access-based fashion business model has drawn both the attention and the anxiety of many fashion retailers (Lee \& Chow, 2020; Schaefers, et al., 2016).

The spread of the fashion sharing platform reflects the overall trend of the sharing economy, but there are other growth factors, first of all, the development of IT. In order to operate a sharing platform, the availability of resources to be shared must be understood in real time, and quick responses must be able to be provided to customers. This requires instantaneous massive data processing technology and the introduction of cloud technology to access information from anywhere (Lee, 2016). Based on these advances in IT, the fashion sharing platform is easily accessible to customers. Currently, the sharing platform business is based on the development of IT to enable consumers to conveniently use the service at the desired time and location. Therefore, in the era of the Fourth Industrial Revolution, the fashion sharing platform, powered by technological factors, is likely to show continuous growth through a more convenient and systematic system (Yoon \& Kim, 2017). Another growth factor is the public's interest in the environment. In fact, the fashion industry has long been severely criticized as one of the largest polluters in the world. Fashion trends change rapidly, and fast fashion attempts to avoid "fashion datedness," causing a substantial increase in the consumption of apparel and fashion-related products. Therefore, the fashion-sharing platform is a service for sharing surplus goods and can be a solution, not only to cause environmental problems by clothing disposal, but also by the production process.

The fashion-sharing platform isn't just about strengths. Fashion products have a rather complicated aspect of sharing in that they are very personal items that are sensitive to fashion, reflect the personality, and are in direct contact with the body (Kim, 2018). Therefore, the sharing economy platform will have to be appropriately supplemented with hygiene and quality control so that it can be competitive. Also, the offerings should be refreshed at times in order to maintain the allure of novelty by keeping pace with rapid market changes. 


\subsection{Consumer Motivation}

Consumers have various demands, and different factors influence individual adoption decisions. Consumer shopping motivation first found wide recognition among marketing scholars in the 1970s (Dennis et al., 2007). Consumer motivation continues to be vividly discussed and is one of the key concepts in research on consumer shopping behavior (Wagner \& Rudolph, 2010). Fundamentally, consumer choices are driven by utilitarian and hedonic considerations (Dhar \& Wertenbroch, 2000). For example, a consumer choosing among new clothes may care about utilitarian attributes such as functionality as well as about hedonic features such as trendy design. Consumers' attitudes towards products depends on their relative utilitarian or hedonic nature (Batra \& Ahtola, 1990; Dhar \& Wertenbroch, 2000).

Utilitarian motivation is concerned with the benefit of acquiring the utility perceived by the consumer as a property of goods and services provided by a company (Carpenter \& Moore, 2009; Seetharaman et al., 2017). In the utilitarian view, consumers are concerned with purchasing products in an efficient and timely manner to achieve their goals with minimal irritation (Childers, et al., 2001). The utilitarian aspects of an attitude toward a behavior relate to the usefulness, value, and wisdom of the behavior as perceived by the customer (Nam et al, 2016). As consumers are replacing trendy items ever faster, they are spending money and time to try new products. Fashion products require a lot of choices, including fashion, design, quality, price, and brand, and there is a constant cost to maintain and repair clothes. Therefore, it can be said that the fashion-sharing economy is practical for handling the complexity and difficulty of selecting and managing fashion products at reasonable cost.

The motivation for shopping can also be the pleasure of pursuing fun. Hedonic motivation affects the interests of the purchase process, such as the sights, fun, pleasure, and diversion, and is used as a self-centered need such as freedom of shopping environment, fantastic needs, escape from reality, and diversion, rather than practicality (Babin et al., 1994). Especially, the hedonic shopping motivation is a robust predictor of purchase intention in online shopping, since this motivation stimulates exploratory informationseeking and impulse buying (Kim \& Eastin, 2011). Hedonic aspects result from the aesthetic or emotional feelings such as love, hate, fear, joy, etc. (Ba et al., 2020). In the hedonic view, shopping is a potential source of entertainment and enjoyment resulting from fun and play (Hirschman \& Holbrook, 1982). Therefore, the hedonic motivation can stimulate consumers to try fashion-sharing platforms for fun and pleasure.

As modern consumers become more diverse, consumer motives appear in various forms besides practical motives and pleasure motives. On a sharing platform, one possible motivation is ecological motivation, which has mainly been studied in the field of recycling and reuse consumption. Previous studies have demonstrated the emergence of ecological motivation as a consumer motivation for the acceptance of the sharing platform (Yoon \& Kim, 2017). Modern consumers push strongly for more sustainable solutions, and this motivation can contribute to the growth of fashion-sharing platforms.

\section{Research Method}

\subsection{Research Model and Hypothesis}

The purpose of this study was to verify the effects of consumer motivations on purchase intention through consumer attitude in the context of fashion-sharing platforms. Based on the theory of reasoned actions, a conceptual research model was constructed as shown in Figure 1.

In this study, the model was designed focusing on the utilitarian, hedonic, and ecological motivations. Product replacement cycle was adopted to investigate the moderating effects on consumer attitude stemming from ecological motivation and on purchase intention from consumer attitude.

\subsubsection{Consumer Motivations and Consumer Attitude}

An increasing number of retailers have innovated their business models to provide a platform that facilitates renting or sharing of clothing items between consumers and/ or the retailer (Perlacia et al,, 2017; Yuan \& Shen, 2019). This research examines motivational factors that influence consumers' attitudes toward fashion-sharing platforms. This is because understanding consumer motives can lead to the strategic success of new businesses via understanding consumer attitudes toward new business models.

In this study, three approaches to consumer motives are classified. The first is divided into utilitarian motivation,

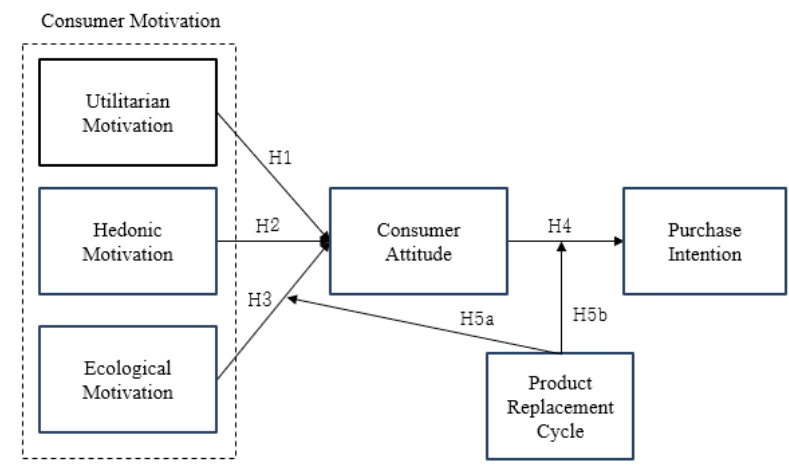

Figure 1: Research Model 
which is intended for destination-oriented and practical results, and the second is hedonic motivation, which is selfcentered and represents the fun in the shopping process. Third is environmental motivation, which reflects consumers' ecological concerns. This psychological motivation can influence the intention to use a fashion- sharing platform (Guiot \& Roux, 2010; Yoon \& Kim, 2017). Thus, the following hypotheses are proposed:

Hypothesis 1: Consumers' utilitarian motivation for using a fashion-sharing platform will have a positive effect on their attitudes.

Hypothesis 2: Consumers' hedonic motivation for using a fashion-sharing platform will have a positive effect on their attitudes.

Hypothesis 3: Consumers' ecological motivation for using a fashion-sharing platform will have a positive effect on their attitudes.

\subsubsection{Consumer Attitude and Purchase Intention}

Attitude denotes personal evaluations of performing a behavior being favorable or unfavorable and is determined by attitudinal beliefs and outcome evaluations, which means people are more likely to undertake a certain behavior if they have a positive attitude toward undertaking it (Nguyen, 2019). Many studies have proven the association between consumers' attitudes and their behavioral intentions (Litvin \& MacLaurin, 2001; O'cass \& Fenech, 2003; Park \& Cho, 2012). This study investigates the relationship between customer attitude and purchase intention in the context of fashion-sharing platforms. Thus, the following hypothesis is proposed:

Hypothesis 4: Consumers' attitudes toward fashionsharing platforms will have a positive effect on their purchase intentions.

\subsubsection{Product Replacement Cycle, Consumer Attitude, and Purchase Intention}

The length or duration of the product replacement cycle is the time interval between purchases (Evans, 1993). In the context of fashion products, product consumption and replacement can be motivated by not only the economic or physiological utility of products, but also social influences. For example, conspicuous consumption of fashion products is common, which means consumers are motivated by a desire to impress others with new items.

The fashion-sharing platform is a business model aimed at customers who frequently want to replace various fashion items by utilizing the characteristics of the fast-moving market (Yuan \& Shen, 2019). In particular, if consumers are environmentally concerned, but inclined to replace their products frequently, they may be more positive about the sharing platform. Therefore, the product replacement cycle may have a moderating effect on the relationship between environmental motivation and consumer attitude toward fashion-sharing platforms. Also, even if the consumer attitude toward the sharing platform is related to the final purchase intention, the product replacement cycle of the consumer may have a moderating effect. Thus, the following hypotheses are proposed:

Hypothesis 5a: Consumers' product replacement cycle for fashion products will have a moderating effect on their attitudes toward fashion-sharing platforms.

Hypothesis 5b: Consumers' product replacement cycle for fashion products will have a moderating effect on purchase intention on fashion-sharing platforms.

\subsection{Measurement and Analytical Approach}

This study conducted a survey to collect the data needed to analyze this model. To construct the survey, the items presented in Table 1 were used based on previous studies. Utilitarian motivation is shopping motivation that expects destination-oriented and practical results. Hedonic motivation is a shopping motivation for the fun of the shopping process. Ecological motivation is a shopping motivation that reflects the consumer's concern for the environment. Consumer attitude refers to the degree to which the consumer favors the fashion sharing platform. Finally, purchase intention is the decision to embrace the fashion-sharing platform, continue using it, and even recommend it to friends. The product replacement cycle is how often consumers buy and replace apparel products. A high product replacement cycle means that consumers frequently replace apparel products, while a low product replacement cycle means that consumers use clothing products for a relatively long time.

And the survey mainly introduced online fashion rental services such as Rent the Runway. Consumers can select the service as pay per service or regular subscription and the service providers deliver products to the customers. Emerging sharing platforms are reconstructed by ICT in the era of the sharing economy. South Korea has advanced information and communication technologies (ICT) and new innovations spread fast and widely among consumers (Yoo et al., 2005).

The survey items were designed with a five-point Likert scale $(1=$ strongly disagree, $5=$ strongly agree $)$, and the measurement items for each variable were designed based on previous research (Table 1). The items to measure utilitarian motivation were adopted from Babin et al. (1994), the items for hedonic motivation were adopted from Babin et al. (1994) and Guido (2006), and the items for ecological 
Table 1: Measurement of Main Constructs

\begin{tabular}{|l|l|l|}
\hline Constructs & \multicolumn{1}{|c|}{ Items } & \multicolumn{1}{|c|}{ Source } \\
\hline $\begin{array}{l}\text { Utilitarian Motivation } \\
\text { (UM) }\end{array}$ & $\begin{array}{l}\text { UM1. While shopping, I find just the item(s) I am looking for. } \\
\text { UM2. A good store visit is when the visit is over quickly. }\end{array}$ & Babin et al. (1994) \\
\hline Hedonic Motivation (HM) & $\begin{array}{l}\text { HM1. Shopping gets me up and doing something physically active. } \\
\text { HM2. Compared to other things I could have done, the time spent } \\
\text { shopping was truly enjoyable. } \\
\text { HM3. I enjoyed being immersed in exciting new products. }\end{array}$ & $\begin{array}{l}\text { Babin et al. (1994); } \\
\text { Guido (2006) }\end{array}$ \\
\hline $\begin{array}{l}\text { Ecological Motivation } \\
\text { (EM) }\end{array}$ & $\begin{array}{l}\text { EM1. It is important to me that the products I use do not harm the } \\
\text { environment. } \\
\text { EM2. I am concerned about wasting the resources of our planet. } \\
\text { EM3. I would describe myself as environmentally responsible. }\end{array}$ & Haws et al. (2010) \\
\hline Consumer Attitude (CA) & $\begin{array}{l}\text { CA1. Using the sharing platform is a good idea. } \\
\text { CA2. Using the sharing platform is a wise idea. } \\
\text { CA3. I like the idea of using the sharing platform. }\end{array}$ & $\begin{array}{l}\text { Ajzen \& Fishbein } \\
\text { (1975); Davis (1989); } \\
\text { Venkatesh et al. (2003) }\end{array}$ \\
\hline Purchase Intention (PI) & $\begin{array}{l}\text { PI1. I will recommend the sharing platform to others. } \\
\text { PI2. I will use the sharing platform continually once I start using it. } \\
\text { PI3. I will consider using the sharing platform. }\end{array}$ & $\begin{array}{l}\text { Putrevu and Lord } \\
\text { (1994); Kim (2013) }\end{array}$ \\
\hline $\begin{array}{l}\text { Product Replacement } \\
\text { Cycle (PRC) }\end{array}$ & $\begin{array}{l}\text { PRC1. I buy clothing frequently because I like having something } \\
\text { new. } \\
\text { PRC2. I like stores that receive new styles frequently. }\end{array}$ & Melser \& Syed (2016) \\
\hline
\end{tabular}

motivation were adopted from Haws et al. (2010). The items for consumer attitude were adopted and modified from Ajzen \& Fishbein (1975), Davis (1989) and Venkatesh et al. (2003), and the items for purchase intention were adopted and modified from Putrevu and Lord (1994) and Kim (2013). Product replacement cycle was adopted from Melser and Syed (2016) focusing on the frequency of purchase of fashion items.

The data for this study were collected via a web survey through fashion-related online communities and college student associations in South Korea in July 2019. The final sample consisted of 180 respondents who had experienced commercially-available rental or sharing products or services. The data were analyzed with SPSS 25.0 for demographic characteristics, descriptive statistics of the parameters, and normality. AMOS 25.0 was selected for the structural equation to find out relations by illustrating regression analysis and path analysis.

\section{Results and Discussion}

\subsection{Respondents' Demographics}

The participants comprised $71.7 \%$ females and $28.3 \%$ males. The age range of the respondents was from 18 to 59 years old, with $37.2 \%$ under the age of $29,51.7 \%$ in their $30 \mathrm{~s}, 7.8 \%$ in their $40 \mathrm{~s}$, and $3.3 \%$ aged 50 and above; thus, participants in their 30s formed the largest group As for educational background, the majority of respondents were associate's and bachelor's degree holders (83.9\%). In terms of occupation, $58.3 \%$ had an office/professional job, $19.4 \%$ a technical/service job, $8.3 \%$ a private business, and so on. Thus, participants with office/professional jobs comprised the largest proportion. Details are shown in Table 2.

\subsection{Analysis Results of Validity and Reliability}

In order to analyze the validity and reliability of the structural equation model, the standard loading value, standard error, t-value, p-value, composite reliability (CR), average variance extracted (AVE), and Cronbach's alpha indices are considered. Table 3 shows the evaluation results for convergent validity and the reliability of the measurement model. Since the standard loading values of each construct are 0.4 or higher and the Cronbach's alpha value of each construct is 0.6 or higher with statistical significance, the convergent validity is obtained. The range of $\mathrm{CR}$ is from 0.688 to 0.898 , so internal reliability is secured. The range of standard loading values is from 0.688 to 0.879 , while each construct is statistically significant at $p<0.001$. The Cronbach's alpha value ranges from 0.682 to 0.888 , and the AVE value ranges from 0.524 to 0.746 .

For correlation analysis, if the square root of the AVE obtained between each pair of latent variables is greater than the correlation coefficient of each latent variable, then discriminant validity between each pair of latent variables can be obtained. Based on these criteria, this study analyzed the AVE and correlation coefficients between latent 
Table 2: Demographics of Survey Participants

\begin{tabular}{|c|c|c|c|}
\hline \multicolumn{2}{|r|}{ Category } & Frequency & Percent (\%) \\
\hline \multirow{3}{*}{ Gender } & Male & 51 & 28.3 \\
\hline & Female & 129 & 71.7 \\
\hline & Total & 180 & 100.0 \\
\hline \multirow{5}{*}{ Age } & Under 29 & 67 & 37.2 \\
\hline & $30 \mathrm{~s}$ & 93 & 51.7 \\
\hline & $40 \mathrm{~s}$ & 14 & 7.8 \\
\hline & 50 s or older & 6 & 3.3 \\
\hline & Total & 180 & 100.0 \\
\hline \multirow{5}{*}{ Education } & Less than high school graduate & 21 & 11.7 \\
\hline & Associate's degree & 38 & 21.1 \\
\hline & Bachelor's degree & 113 & 62.8 \\
\hline & Master's degree or above & 8 & 4.4 \\
\hline & Total & 180 & 100.0 \\
\hline \multirow{7}{*}{ Occupation } & Office/professional job & 105 & 58.3 \\
\hline & Technical/service job & 35 & 19.4 \\
\hline & Private business & 15 & 8.3 \\
\hline & Housewife & 11 & 6.1 \\
\hline & Student & 6 & 3.3 \\
\hline & Unemployed/etc. & 8 & 4.4 \\
\hline & Total & 180 & 100.0 \\
\hline
\end{tabular}

Table 3: Results of Reliability and Convergent Validity Test

\begin{tabular}{|c|c|c|c|c|c|c|c|c|c|}
\hline Category & Constructs & Items & $\begin{array}{l}\text { Standard } \\
\text { loading } \\
\text { value }\end{array}$ & $\begin{array}{l}\text { Standard } \\
\text { error }\end{array}$ & t-value & $p$-value & CR & AVE & Cronbach's $\alpha$ \\
\hline \multirow{8}{*}{$\begin{array}{l}\text { Independent } \\
\text { variable }\end{array}$} & \multirow{2}{*}{$\begin{array}{l}\text { Utilitarian } \\
\text { motivation }\end{array}$} & UM1 & 0.698 & & & & \multirow[t]{2}{*}{0.708} & \multirow[t]{2}{*}{0.548} & \multirow[t]{2}{*}{0.682} \\
\hline & & UM2 & 0.741 & 0.304 & 3.937 & $* * *$ & & & \\
\hline & \multirow{3}{*}{$\begin{array}{l}\text { Hedonic } \\
\text { motivation }\end{array}$} & HM1 & 0.748 & & & & \multirow[t]{3}{*}{0.815} & \multirow[t]{3}{*}{0.595} & \multirow[t]{3}{*}{0.804} \\
\hline & & HM2 & 0.796 & 0.118 & 9.207 & $* * *$ & & & \\
\hline & & HM3 & 0.737 & 0.113 & 8.788 & $* * *$ & & & \\
\hline & \multirow{3}{*}{$\begin{array}{l}\text { Ecological } \\
\text { motivation }\end{array}$} & EM1 & 0.720 & & & & \multirow[t]{3}{*}{0.834} & \multirow[t]{3}{*}{0.627} & \multirow[t]{3}{*}{0.794} \\
\hline & & EM2 & 0.747 & 0.125 & 8.42 & $* * *$ & & & \\
\hline & & EM3 & 0.796 & 0.114 & 8.64 & $* * *$ & & & \\
\hline \multirow[t]{3}{*}{ Parameter } & \multirow{3}{*}{$\begin{array}{l}\text { Consumer } \\
\text { attitude }\end{array}$} & CA1 & 0.754 & & & & \multirow[t]{3}{*}{0.813} & \multirow[t]{3}{*}{0.592} & \multirow[t]{3}{*}{0.764} \\
\hline & & CA2 & 0.688 & 0.11 & 8.013 & $* * *$ & & & \\
\hline & & CA3 & 0.714 & 0.111 & 8.244 & $\star * \star$ & & & \\
\hline \multirow{3}{*}{$\begin{array}{l}\text { Dependent } \\
\text { variable }\end{array}$} & \multirow{3}{*}{$\begin{array}{l}\text { Purchase } \\
\text { intention }\end{array}$} & $\mathrm{PI1}$ & 0.879 & & & & \multirow[t]{3}{*}{0.898} & \multirow[t]{3}{*}{0.746} & \multirow[t]{3}{*}{0.888} \\
\hline & & $\mathrm{Pl} 2$ & 0.819 & 0.07 & 13.463 & $* * *$ & & & \\
\hline & & PI3 & 0.860 & 0.063 & 14.437 & $* * *$ & & & \\
\hline \multirow[t]{2}{*}{ Moderator } & \multirow{2}{*}{$\begin{array}{l}\text { Product } \\
\text { replacement } \\
\text { cycle }\end{array}$} & PLC1 & 0.739 & & & & \multirow[t]{2}{*}{0.688} & \multirow[t]{2}{*}{0.524} & \multirow[t]{2}{*}{0.706} \\
\hline & & PLC2 & 0.737 & 0.113 & 7.683 & $* * *$ & & & \\
\hline
\end{tabular}

Note: Goodness of fit indices: Satorra-Bentler scaled $X^{2}=123.286, \mathrm{df}=89 ; \mathrm{S}-\mathrm{B} \mathrm{X}^{2} / \mathrm{df}=1.385 ; \mathrm{RMR}=0.041 ; \mathrm{GFI}=0.926 ; \mathrm{AGFI}=0.887$; $\mathrm{NFI}=0.902 ; \mathrm{TLI}=0.959 ; \mathrm{CFI}=0.970 ; \mathrm{RMSEA}=0.046,{ }^{*} \mathrm{p}<0.05,{ }^{* *} \mathrm{p}<0.01,{ }^{* * *} \mathrm{p}<0.001$. 
variables. As shown in Table 4, the square root of the AVE of each latent variable is larger than the correlation coefficients between latent variables, confirming discriminant validity.

\subsection{Analysis Results of Structural Model}

Table 5 shows the results of evaluating the fitness of the structural model, and the $t$ variable is larger than the correlation of freedom, at 1.511. By the fitness standards, the goodness-of-fit index (GFI) is 0.929, normal fit index (NFI) is 0.903 , and root mean square error of approximation (RMSEA) is 0.053 . The comparative fit index (CFI) and the Tucker-Lewis coefficient (TLI), which indicate the explanatory power of the model without being influenced by the sample, are 0.953 and 0.964 , respectively, indicating that the final model has excellent fit.

Based on the hypothesis testing through the structural equation model path analysis, one of the four hypotheses was rejected, as presented in Table 6 . The hypothesis verification with the final model revealed that hedonic and ecological motivations are positively statistically significant on the consumer attitude toward the fashion-sharing platform. The channel coefficients are $0.318(\mathrm{p}<0.001)$ and $0.364(\mathrm{p}<$ 0.001 ), respectively. However, utilitarian motivation does not affect the consumer attitude $(p=0.218)$, which means utilitarian motivation does not have a statistically significant effect on the consumer attitude toward the fashion-sharing platform. Finally, the consumer attitude has a statistically significant effect on the purchase intention on the fashionsharing platform, with channel a coefficient of $0.680(\mathrm{p}$ $<0.001$ ). Therefore, all hypotheses are adopted except hypothesis 1 . The hypothesis test results are shown in Table 6.

\subsection{Mediated Effects}

In order to verify the significance of the indirect effect, direct, indirect, and total effects were derived using the Sobel test method, which calculates the statistics with

Table 4: Correlation Matrix and AVE

\begin{tabular}{|l|c|c|c|c|c|c|c|}
\hline \multicolumn{1}{|c|}{ Category } & AVE & $\begin{array}{c}\text { Utilitarian } \\
\text { motivation }\end{array}$ & $\begin{array}{c}\text { Hedonic } \\
\text { motivation }\end{array}$ & $\begin{array}{c}\text { Ecological } \\
\text { motivation }\end{array}$ & $\begin{array}{c}\text { Consumer } \\
\text { attitude }\end{array}$ & $\begin{array}{c}\text { Purchase } \\
\text { intention }\end{array}$ & $\begin{array}{c}\text { Product } \\
\text { replacement } \\
\text { cycle }\end{array}$ \\
\hline Utilitarian motivation & 0.548 & 0.740 & & & & \\
\hline Hedonic motivation & 0.595 & 0.143 & 0.771 & & & \\
\hline Ecological motivation & 0.627 & 0.412 & 0.324 & 0.792 & & \\
\hline Consumer attitude & 0.592 & 0.327 & 0.404 & 0.519 & 0.769 & \\
\hline Purchase intention & 0.746 & 0.205 & 0.452 & 0.348 & 0.659 & 0.864 & \\
\hline $\begin{array}{l}\text { Product replacement } \\
\text { cycle }\end{array}$ & 0.524 & 0.192 & 0.687 & 0.265 & 0.392 & 0.647 & 0.724 \\
\hline
\end{tabular}

Note: The numbers in bold are the AVE square root values of each variable.

Table 5: Model Fit Indices for the Structural Model

\begin{tabular}{|c|c|c|c|c|c|c|c|c|c|c|c|}
\hline Model & $\mathbf{X}^{2}$ & $\mathbf{p}$ & $\mathbf{d f}$ & $\mathbf{X}^{2} / \mathbf{d f}$ & $\mathbf{R M R}$ & $\mathbf{G F I}$ & $\mathbf{A G F I}$ & $\mathbf{N F I}$ & $\mathbf{C F I}$ & TLI & RMSEA \\
\hline $\begin{array}{l}\text { Original } \\
\text { model }\end{array}$ & 105.802 & 0.004 & 70 & 1.511 & 0.049 & 0.929 & 0.894 & 0.903 & 0.953 & 0.964 & 0.053 \\
\hline
\end{tabular}

Table 6: Results of Hypothesis Test

\begin{tabular}{|l|c|c|c|c|}
\hline \multicolumn{1}{|c|}{ Hypothesis (Channel) } & $\begin{array}{c}\text { Channel } \\
\text { coefficient }\end{array}$ & t-value & p-value & $\begin{array}{c}\text { Adopted or } \\
\text { dismissed }\end{array}$ \\
\hline H1. Utilitarian motivation $\rightarrow$ Consumer attitude & 0.128 & 1.233 & 0.218 & Dismissed \\
\hline H2. Hedonic motivation $\rightarrow$ Consumer attitude & 0.318 & 3.406 & $* * *$ & Adopted \\
\hline H3. Ecological motivation $\rightarrow$ Consumer attitude & 0.364 & 3.439 & $* * *$ & Adopted \\
\hline H4. Consumer attitude $\rightarrow$ Purchase intention & 0.680 & 7.316 & $* * *$ & Adopted \\
\hline
\end{tabular}

Note: ${ }^{*} p<0.05,{ }^{* *} p<0.01,{ }^{* *} p<0.001$ 
standard error. As shown in Table 7, considering the detailed factors of customer motivations, it was found that the two factors of utilitarian motivation (Sobel $\mathrm{z}=2.959$ ) and ecological motivation (Sobel $\mathrm{z}=4.530$ ) have no effect on purchase intention through customer attitude. On the other hand, hedonic motivation (Sobel $\mathrm{z}=3.832$ ) affects purchase intention through customer attitude.

Based on the hypothesis testing through the structural equation model path analysis, one of the four hypotheses was rejected, as presented in Table 6 . The hypothesis verification with the final model revealed that hedonic and ecological motivations are positively statistically significant on the consumer attitude toward the fashion-sharing platform. The channel coefficients are $0.318(\mathrm{p}<0.001)$ and $0.364(\mathrm{p}<$ 0.001 ), respectively. However, utilitarian motivation does not affect the consumer attitude $(\mathrm{p}=0.218)$, which means utilitarian motivation does not have a statistically significant effect on the consumer attitude toward the fashion-sharing platform. Finally, the consumer attitude has a statistically significant effect on the purchase intention on the fashionsharing platform, with channel a coefficient of 0.680 (p $<0.001)$. Therefore, all hypotheses are adopted except hypothesis 1 . The hypothesis test results are shown in Table 6.

\subsection{Comparison Analysis Result}

A moderating effect analysis was conducted to investigate the effects from the consumers' product replacement cycle. For this analysis, we divided the consumers into two groups based on their product replacement cycle measurements.
The first group comprises consumers with a high product replacement cycle (PRC high), which means the consumers purchased or changed their items frequently and includes $48.0 \%$ of consumers ( 87 out of 180 ). The second group comprises consumers with a low product replacement cycle (PRC low), which means the consumers purchases or change their items less frequently and includes $52.0 \%$ of consumers (93 out of 180). The result indicates that the model for the moderating effect of product replacement cycle has a good fit $(\chi 2=1.08, \mathrm{df}=2, \mathrm{p}=0.583 ; \mathrm{NFI}=0.001 ; \mathrm{IFI}=0.001$; RFI $=-0.002$; TLI $=-0.002)$. The analysis results show that the moderating effect of product replacement cycle is statistically significant $(\mathrm{p}=0.583)$.

The moderating effects of customers with a high product replacement cycle are statistically significant between the ecological motivation and consumer attitude, while the moderating effects of customers with a low product replacement cycle are not statistically significant between the two variables. Customers who tend to purchase and replace fashion items frequently show a positive relationship between the ecological motivation and consumer attitude. Regarding the relationship between consumer attitude and purchase intention, customers with both high and low product replacement cycles show statistically significant moderating effects, as shown in Table 8.

\section{Conclusion}

This study discovered the relationships between customer motivations and purchase intention through consumer

Table 7: Results of Mediated Effects

\begin{tabular}{|c|c|c|c|c|}
\hline Dependent variable & Explanatory variable & Direct effect & Indirect effect & Total effect \\
\hline \multirow{4}{*}{ Purchase intention } & Consumer attitude & 0.680 & - & 0.680 \\
\cline { 2 - 5 } & Utilitarian motivation & - & 0.029 & 2.959 \\
\cline { 2 - 5 } & Hedonic motivation & - & $0.235^{\star * *}$ & 3.832 \\
\cline { 2 - 5 } & Ecological motivation & - & 0.091 & 4.530 \\
\hline
\end{tabular}

Note: ${ }^{*} p<0.05,{ }^{* *} p<0.01,{ }^{* * *} p<0.001$

Table 8: The Moderating Analysis by Product Replacement Cycle

\begin{tabular}{|c|c|c|c|c|c|c|c|c|}
\hline & \multicolumn{4}{|c|}{ PRC High } & \multicolumn{4}{|c|}{ PRC Low } \\
\hline & $\begin{array}{l}\text { Channel } \\
\text { coefficient }\end{array}$ & SE & t-value & $\begin{array}{c}\mathrm{p}- \\
\text { value }\end{array}$ & $\begin{array}{l}\text { Channel } \\
\text { coefficient }\end{array}$ & SE & $\mathrm{t}$-value & $p$-value \\
\hline $\begin{array}{l}\text { H5a. Ecological motivation } \\
\rightarrow \text { Consumer attitude }\end{array}$ & 0.482 & 0.112 & 3.598 & $* * *$ & 0.323 & 0.186 & 1.715 & 0.086 \\
\hline $\begin{array}{l}\text { H5b. Consumer attitude } \\
\rightarrow \text { Purchase intention }\end{array}$ & 0.740 & 0.173 & 5.163 & $* * *$ & 0.523 & 0.176 & 3.972 & $* * *$ \\
\hline
\end{tabular}

Note: ${ }^{*} p<0.05,{ }^{* *} p<0.01,{ }^{* * *} p<0.001$ 
attitude in the context of a fashion-sharing platform. The results reveal that hedonic motivation has a statistically significant relationship with consumer attitude toward a fashion-sharing platform. Hedonic shoppers tend to enjoy their shopping activities and renting clothes can be a new type of shopping activity that can offer excitement. Shoppers can try diverse items with less cost and effort when the offerings are refreshed periodically on the sharing platforms. This also implies that hedonic shoppers consider clothes as enjoyable objects but do not necessarily seek the ownership of clothes. Another shopping motivation that affects consumer attitude is ecological motivation. The results reveal that ecological motivation has a statistically significant relationship with consumer attitude toward a fashion-sharing platform. Shoppers with ecological concerns lead in collaborative consumption and positively influence the attitude toward fashion-sharing platforms. These consumers seem to believe that the environmental impacts of clothing production and disposal can be reduced by using sharing platforms.

On the other hand, utilitarian motivation does not have a statistically significant effect on consumer attitude. This implies that customers perceive that fashion renting does not offer utilitarian values, such as saving money or maximizing utility. In previous studies, utilitarian motivation is one of the dominant factors in consumers' decisions to pursue accessbased consumption (Lee \& Chow, 2020; Möhlmann, 2015). However, the unique characteristics of fashion items might influence the effect of utilitarian motivation on fashion-sharing platforms, which are trendy and fast changing. In addition, the maturity of market can vary the customer motivations. For example, in the US, which is a relatively mature market for fashion-sharing platforms, some studies show that consumers feel that these platforms are practical, which can be interpreted as showing a phenomenon in a relatively mature market (Kussusanti et al., 2019). As a result, it is necessary to enhance the usefulness, functionality, or efficiency of sharing platforms for customers who have strong utilitarian values in early market entry because utilitarian shopping motivation is essential to decision-making.

This study also examined the regulatory effects of the product replacement cycle. For consumers with short product replacement cycles, the relationship between environmental motivation, consumer attitudes, and purchase intentions was stronger. On the other hand, in the case of consumers who used products for a relatively long time, that is, with a long product replacement cycle, the influence of environmental motivation on the consumer attitude was not statistically significant. For them, environmental concerns did not lead to a positive attitude towards the fashion-sharing platform. Finally, the consumer attitude toward fashion-sharing platforms had a statistically significant effect on purchase intention. As with previous studies, consumer attitudes were strong and positively influenced purchase intentions.
These results enrich previous studies in several respects. First, this is a systematic and quantitative study that identifies motives for shopping for fashion items on sharing platforms. The fashion-sharing platform is a relatively new concept, and very few studies have been conducted on it; those that have mostly focused on case studies and qualitative research. Second, the empirical findings suggest that there are distinct shopping motivations on sharing platforms, which include ecological motivation in addition to the utilitarian and hedonic motivations, the first of which has not been measured in consumer shopping motivation on sharing platforms. The result reveal that ecological motivation strongly and positively affects customers' attitudes. This implies that today's consumers are concerned about the environment, and companies also highlight these features in their marketing strategies to appeal to customers.

This study suggests the potential of a new strategy for using this environmental shopping motive when approaching customers: Collaborative consumption that overcomes environmental guilt can be emphasized through the use of the sharing platform by looking at the clothes that are worn once or twice and discarded or left to languish in the closet. Third, the results of this study show that customers apply different strategies depending on their product replacement cycle. For consumers with short product replacement cycles, environmental motives have shown a strong influence on positive attitudes. For this type of customer, a fashion-sharing platform can be a way to solve the dilemma between fastchanging fashion trends and ecological concerns. On the other hand, for consumers with long product replacement cycles, the relationship between environmental motivation and positive attitude formation is not statistically significant, suggesting that hedonic motivation should be emphasized more.

This study explored primary shopping motivations associated with a fashion-sharing platform. However, the complexity of consumer motivation is oversimplified in this study. Consumer motivation can be further divided. Hedonic motivation can be divided into various submotivations such as curiosity and joy. Looking for more specific incentives will give a more in-depth understanding of consumer attitudes toward and intentions to purchase on fashion-sharing platforms. Second, there are various forms of fashion-sharing platforms, but this research conducted its survey focusing on the fashion rental service sector, with service providers such as Rent the Runway. However, peerto-peer sharing platforms are also on the rise, with variations that will require further study by dividing the business model in more detail. Third, we can study the motives for using a more specific rental situation. This study examined the relationship between shopping motives and the use of fashion-sharing platforms as a kind of consumer-specific 
characteristic. However, we will be able to conduct more concrete and direct research on purchase motivation with respect to the customer's experience on sharing platforms. Furthermore, it would be very interesting to give concrete examples of fashion-sharing platforms and confirm whether consumers choose to buy through experiments.

\section{References}

Ajzen, I., \& Fishbein, M. (1975). Attitudinal vs. normative messages: An investigation of the differential effects of persuasive communication on behavior. Sociometry, 34(1), 263-280.

Ba, H., Le, H., Ngo, C. T., Trinh, T.T.H., \& Nguyen, T.T.P. (2020). Factor affecting customers' decision to use mobile banking service: A case of Thanh Hoa Province, Vietnam. Journal of Asian Finance, Economics and Business, 7(2), 205-212. https:// doi.org/10.13106/jafeb.2020.vo17.no2.205

Babin, B. J., Darden, W. R., \& Griffin, M. (1994). Work and/or fun: measuring hedonic and utilitarian shopping value. Journal of Consumer Research, 20(4), 644-656.

Batra, R., \& Ahtola, O. (1990). Sources of the hedonic and utilitarian measuring attitudes consumer. Consumer Attitudes, 2(2), 159-170.

Carpenter, J. M., \& Moore, M. (2009). Utilitarian and hedonic shopping value in the US discount sector. Journal of Retailing and Consumer Services, 16(1), 68-74.

Childers, T. L., Carr, C. L., Peck, J., \& Carson, S. (2001). Hedonic and utilitarian motivations for online retail shopping behavior. Journal of Retailing, 77(4), 511-535.

Choi, T.-M., \& He, Y. (2019). Peer-to-peer collaborative consumption for fashion products in the sharing economy: Platform operations. Transportation Research Part E: Logistics and Transportation Review, 126(1), 49-65.

Cohen, B., \& Kietzmann, J. (2014). Ride on! Mobility business models for the sharing economy. Organization \& Environment, 27(3), 279-296.

Davis, F. D. (1989). Perceived usefulness, perceived ease of use, and user acceptance of information technology. MIS Quarterly, 13(3), 319-340.

Dennis, C., King, T., \& Wagner, T. (2007). Shopping motivation revised: a means-end chain analytical perspective. International Journal of Retail \& Distribution Management, 35(7), 569-582.

Dhar, R., \& Wertenbroch, K. (2000). Consumer choice between hedonic and utilitarian goods. Journal of Marketing Research, $37(1), 60-71$.

Evans, R. H. (1993). Customers' involvement and the replacement cycle. Psychological Reports, 72(3), 87-90.

Guido, G. (2006). Shopping motives, big five factors, and the hedonic/utilitarian shopping value: An integration and factorial study. Innovative Marketing, 2(2), 57-67.
Guiot, D., \& Roux, D. (2010). A second-hand shoppers' motivation scale: Antecedents, consequences, and implications for retailers. Journal of Retailing, 86(4), 355-371.

Hamari, J., Sjöklint, M., \& Ukkonen, A. (2016). The sharing economy: Why people participate in collaborative consumption. Journal of the Association for Information Science and Technology, 67(9), 47-59.

Haws, K. L., Winterich, K. P., \& Naylor, R. W. (2010). Seeing the world through green-tinted glasses: Motivated reasoning and consumer response to environmentally friendly products. Journal of Macromarketing, 5(2), 18-39.

Hirschman, E. C., \& Holbrook, M. B. (1982). Hedonic consumption: emerging concepts, methods and propositions. Journal of Marketing, 46(3), 92-101.

Kim, G. H. (2018). A case study on fashion-sharing platform by introduction of sharing-economy: Focused on product-service systems. Korea Fashion Design Journal, 18(4), 93-115.

Kim, H. C., \& Kim, J. S. (2013). How Marketing Event and OnSite Communication Work on the Effective Formation of Brand Attitude. Korean Association for Advertising and Public Relations, 15(2), 5-36.

Kim, S., \& Eastin, M. S. (2011). Hedonic tendencies and the online consumer: An investigation of the online shopping process. Journal of Internet Commerce, 10(1), 68-90.

Kussusanti, S., Tjiptoherijanto, P., Halim, R. E., \& Furinto, A. (2019). Informational justice and post-recovery satisfaction in E-commerce: The role of service failure severity on behavioral intentions. Journal of Asian Finance, Economics and Business, 6(1), 129-139. http://doi.org/10.13106/jafeb.2019.vol6.no1.129

Lee, H. J. (2017). The differential factors influencing online and mobile shopping behavior. Journal of Distribution Science, 15(9), 27-36.

Lee, S. H. (2016). A study of servitization strategy for electric vehicles. Journal of Distribution Science, 14(9), 5-13.

Lee, S. H., \& Chow, P. S. (2020). Investigating consumer attitudes and intentions toward online fashion renting retailing. Journal of Retailing and Consumer Services, 52(1), 892-905.

Litvin, S. W., \& MacLaurin, D. J. (2001). Consumer attitude and behavior. Annals of Tourism Research, 28(3), 821-833.

Möhlmann, M. (2015). Collaborative consumption: determinants of satisfaction and the likelihood of using a sharing economy option again. Journal of Consumer Behaviour, 14(3), 193-207.

Mehrjoo, M., \& Pasek, Z. J. (2016). Risk assessment for the supply chain of fast fashion apparel industry: a system dynamics framework. International Journal of Production Research, 54(1), 28-48.

Melser, D. \& Syed, I. A. (2016). Life cycle price trends and product replacement: Implications for the measurement of inflation. The Review of Income and Wealth, 62(3) 509-533.

Nam, J. C., Cho, S. R., \& Lee, H. W. (2016). Customers' satisfaction and loyalty with motivations to dine out and selected attributes 
in Korean traditional restaurant. Journal of Distribution Science, 14(8), 9-21.

Nguyen, H. H. (2019). The study on people's satisfaction towards public services of Viet Nam: Evidence of Tra Vinh provincial center of public administrative services. Journal of Asian Finance, Economics and Business, 6(2), 183-187. https://doi. org/10.13106/jafeb.2019.vol6.no2.183

Nguyen, M. H., \& Khoa, B. T. (2019). Customer electronic loyalty towards online business: The role of online trust, perceived mental benefits and hedonic value. Journal of Distribution Science, 17(12), 81-93.

O'cass, A., \& Fenech, T. (2003). Web retailing adoption: exploring the nature of internet users Web retailing behaviour. Journal of Retailing and Consumer Services, 10(2), 81-94.

Ozdamar-Ertekin, Z. (2016). Conflicting perspectives on speed: Dynamics and consequences of the fast fashion system. Markets, Globalization \& Development Review, 1(1), 1-36.

Parguel, B., Lunardo, R., \& Benoit-Moreau, F. (2017). Sustainability of the sharing economy in question: When second-hand peer-topeer platforms stimulate indulgent consumption. Technological Forecasting and Social Change, 25(1), 48-57.

Park, S. H., \& Cho, W. J. (2012). The structural relationship between consumer values, attitude and purchase intention towards healthy menu items at fast food restaurants. International Journal of Tourism Management and Science, 27(2), 179-194.

Perlacia, A. S., Duml, V., \& Saebi, T. (2017). Collaborative consumption: Live fashion, don't own it. Beta, 31(1), 6-24.

Putrevu, S., \& Lord, K. R. (1994). Comparative and noncomparative advertising: Attitudinal effects under cognitive and affective involvement conditions. Journal of Advertising, 23(2), 77-91.

Richardson, L. (2015). Performing the sharing economy. Geoforum, 67(1), 121-129.
Rong, K., Hu, J., Ma, Y., Lim, M. K., Liu, Y., \& Lu, C. (2018). The sharing economy and its implications for sustainable value chains. Resources, Conservation and Recycling, 30(1), 188189.

Schaefers, T., Lawson, S. J., \& Kukar-Kinney, M. (2016). How the burdens of ownership promote consumer usage of access-based services. Marketing Letters, 27(3), 569-577.

Seetharaman, A., Saravanan, A.S., Patwa, N., \& Bey, J. M. (2017). The Impact of Property Management Services on Tenants' Satisfaction with Industrial Buildings. Journal of Asian Finance, Economics and Business, 4(3), 57-73. http://dx.doi. org/10.13106/jafeb.2017.vol4.no3.57

Shin, M. H., Lee, Y. M., \& Kim, J. H. (2019). Impact factors analysis on AR shopping service's immersion. Journal of Distribution Science, 17(12), 13-21.

Venkatesh, V., Morris, M. G., Davis, G. B., \& Davis, F. D. (2003). User acceptance of information technology: Toward a unified view. MIS Quarterly, 27(3), 425-478.

Wagner, T., \& Rudolph, T. (2010). Towards a hierarchical theory of shopping motivation. Journal of Retailing and Consumer Services, 17(5), 415-429.

Yoo, Y., Lyytinen, K., \& Yang, H. (2005). The role of standards in innovation and diffusion of broadband mobile services: The case of South Korea. The Journal of Strategic Information Systems, 14(1), 323-353.

Yoon, J. Y., \& Kim, S. I. (2017). A Study on Development of Fashion Sharing Platform for Shared Economy: Focusing on fashion rental service case. Journal of the Korea Convergence Society, 8(7), 199-205.

Yuan, Q., \& Shen, B. (2019). Renting fashion with strategic customers in the sharing economy. International Journal of Production Economics, 28(1), 185-195. 